\title{
OVERVIEW OF POST-COMBUSTION NOX EMISSION CONTROL MECHANISM IN INDIAN COAL FIRED POWER PLANTS
}

\author{
Arun Minj \\ Department Of Mechanical Engineering \\ Jharkhand Rai University, Ranchi, \\ Jharkhand, INDIA
}

\begin{abstract}
The importance of Coal in generation of electricity is well established. But, during the combustion of coal for generation of electricity, oxides of nitrogen $\left(\mathrm{NO}_{\mathrm{x}}\right)$ are also released. These oxides of nitrogen are pollutants which have an adverse effect on both the human life as well as the environment. Due to the increased pollution level from Coal Fired Power Plants, Ministry of Environment \& Forests (MOE\&F) on Dec 2015, announced stringent standards for coal based thermal power plants under the Environment Protection Act of 1986. Though various $\mathrm{NO}_{\mathrm{x}}$ control systems have been installed and functioning properly worldwide, but their provenness in the Indian scenario is yet to be established. As the coal in which the Indian power plants operates have a very different characteristics than the coal used abroad for power plants. This paper aims to address and explore the various methods and challenges in reducing the NOx emissions from Coal Fired Power Plants while firing Indigenous coal.
\end{abstract}

\section{INTRODUCTION}

Fossil fuels, and in particular coal, is the main input fuel to the Power Sector in the current scenario. Also, coal is, and will continue in the near future to be the backbone of Indian Power Plants.

Out of the total installed capacity of 3,70,106 MW of Power Plants in India, approx. 2,30,600 MW (i.e. $62.31 \%$ of the installed capacity) is from Thermal Power Plants. And out of which, $55.43 \%$ is through Coal Based. ${ }^{[1]}$

These Thermal Power Plants mostly use the primary fuel as coal, i.e. combustion of coal inside the power plant furnace is the primary medium of generating heat for producing electricity.

But, apart from generating electricity, combustion of coal is also responsible for generating a significant amount of air borne pollutants including carbon dioxide, $\left.\mathrm{CO}_{2}\right)$, sulphur dioxide $\left(\mathrm{SO}_{2}\right)$, nitrogen oxides $\left(\mathrm{NO}_{\mathrm{x}}\right)$, particulate matter $(\mathrm{PM})$, various trace metals including mercury $(\mathrm{Hg})$.
Table-1 : Sector wise Contribution (as on 31.03.2020) ${ }^{[1]}$

\begin{tabular}{|l|l|}
\hline SECTOR & $\begin{array}{l}\text { CAPACITY, } \\
\text { MW }\end{array}$ \\
\hline Total Installed Capacity & $3,70,106$ \\
\hline Coal & $2,05,135$ \\
\hline Gas & 24,955 \\
\hline Oil & 510 \\
\hline Nuclear & 6,780 \\
\hline Hydro & 45,699 \\
\hline RES & 87,028 \\
\hline
\end{tabular}

India did not have standards for the emission of sulphur oxide, nitrogen oxides and mercury until December 2015. The only standards that existed before Dec 2015 were for particulate matter (tiny pollutant particles).

Considering India's own initiative to go green, the Indian Ministry of Environment, Forests \& Climate Change (MOEFCC) was committed for stringent new standards to regulate $\mathrm{NO}_{\mathrm{x}}, \mathrm{SO}_{\mathrm{x}}$, particulate matter and mercury emissions from coal fired power plants. Hence, in December 2015, MOEFCC announced tighter standards for coal-based thermal power plants under the Amendment to Environment Protection Act of 1986. These are indicated in Table $-2 .^{[2]}$.

Table-2 : MOEF Norms Dec 2015. ${ }^{[2]}$

\begin{tabular}{|l|l|l|l|}
\hline Pollutants & $\begin{array}{l}\text { TPPs } \\
\text { (units) } \\
\text { be } \\
\text { installed } \\
\text { after } \\
\mathbf{0 1 . 0 1 . 2 0 1 7} .\end{array}$ & $\begin{array}{l}\text { TPPs } \\
\text { (units) } \\
\text { installed } \\
\text { between } \\
\mathbf{0 1 . 0 1 . 2 0 0 4} \\
\text { and } \\
\text { 31.12.2016. }\end{array}$ & $\begin{array}{l}\text { TPPs ( units) } \\
\text { installed } \\
\text { before } \\
\text { 31 Dec 2003. }\end{array}$ \\
\hline $\begin{array}{l}\text { Matter } \\
\text { (PM) }\end{array}$ & $30 \mathrm{mg} / \mathrm{Nm}^{3}$ & $50 \mathrm{mg} / \mathrm{Nm}^{3}$ & $100 \mathrm{mg} / \mathrm{Nm}^{3}$ \\
\hline $\begin{array}{l}\text { Oxides of } \\
\text { Nitrogen } \\
\left(\mathrm{NO}_{x}\right)\end{array}$ & $100 \mathrm{mg} / \mathrm{Nm}^{3}$ & $300 \mathrm{mg} / \mathrm{Nm}^{3}$ & $600 \mathrm{mg} / \mathrm{Nm}^{3}$ \\
\hline
\end{tabular}




\section{International Journal of Engineering Applied Sciences and Technology, 2021 \\ Vol. 6, Issue 3, ISSN No. 2455-2143, Pages 225-230 \\ Published Online July 2021 in IJEAST (http://www.ijeast.com)}

\begin{tabular}{|l|l|l|l|}
\hline $\begin{array}{l}\text { Sulphur } \\
\text { Dioxide } \\
\left(\mathrm{SO}_{2}\right)\end{array}$ & $100 \mathrm{mg} / \mathrm{Nm}^{3}$ & $\begin{array}{l}600 \mathrm{mg} / \mathrm{Nm}^{3} \\
\text { (For units } \\
<500 \mathrm{MW})\end{array}$ & $\begin{array}{l}600 \mathrm{mg} / \mathrm{Nm}^{3} \\
(\text { For units } \\
<500 \mathrm{MW})\end{array}$ \\
& & $\begin{array}{l}\text { 200 } \mathrm{mg} / \mathrm{Nm}^{3} \\
\text { (For units } \\
500 \mathrm{MW})\end{array}$ & $\begin{array}{l}200 \mathrm{mg} / \mathrm{Nm}^{3} \\
(\text { For units } \\
500 \mathrm{MW})\end{array}$ \\
\hline $\begin{array}{l}\text { Mercury } \\
(\mathrm{Hg})\end{array}$ & $0.03 \mathrm{mg} / \mathrm{Nm}^{3}$ & $0.03 \mathrm{mg} / \mathrm{Nm}^{3}$ & $0.03 \mathrm{mg} / \mathrm{Nm}^{3}$ \\
\hline
\end{tabular}

These new norms will affect the existing 2,05,135 MW and under construction $64,861.15 \mathrm{MW}^{[3]}$ coal based thermal power plants.

Though various $\mathrm{NO}_{\mathrm{x}}$ control systems have been installed and functioning properly worldwide, but their proveneness with the Indian coal is yet to be established. ${ }^{[4]}$

Several deliberations regarding this issue have taken place at different platforms, but effectiveness of any technology is yet to be established for the high ash Indian coals and even with the passage of about 5 years since the announcement of these norms, any benchmark project for post combustion NOx control for high ash Indian coal is yet to set up.

The initial deadlines for adherence to these norms were by Dec 2017. But, after considering the complications involved, the deadline for complying with the emission norms has been extended till 2023-2024, by the Indian Ministry of Environment, Forests \& Climate Change (MOEFCC).

\section{LITERATURE REVIEW}

\section{Harmful Effects of $\mathrm{NO}_{\mathrm{x}}$}

The harmful effects of NOx include formation of ground level ozone, acid rain, particulate matters, toxic chemicals, deterioration in water quality and global warming which are known to cause a wide variety of health and environmental impacts.

\section{Estimates of Annual NO emissions}

As per a separate research on "Estimates of Emission from Coal Fired Thermal Power Plants in India", the region wise annual NO emission from 2001 to 2010 are summed up in Table $-3 \& 4$ below. ${ }^{[4]}$

\section{Table-3 : Region wise NO emission (Gg)} during 2001-02 to 2009-10 ${ }^{[4]}$

\begin{tabular}{|l|l|l|l|l|l|}
\hline & Northern & Western & Southern & Eastern & India \\
\hline $2001-02$ & 447.05 & 510.06 & 332.86 & 212,10 & 1502.07 \\
\hline $2002-03$ & 464.52 & 543.33 & 369.05 & 224.35 & 1601.25 \\
\hline $2003-04$ & 511.53 & 541.42 & 361.46 & 262.01 & 1676.42 \\
\hline $2004-05$ & 499.13 & 567.06 & 366.9 & 284.46 & 1717.56 \\
\hline $2005-06$ & 523.38 & 564.68 & 349.23 & 306.49 & 1743.78 \\
\hline $2006-07$ & 594.73 & 628.77 & 383.24 & 341.29 & 1948.03 \\
\hline $2007-08$ & 603.75 & 720.07 & 413.11 & 352.09 & 2089.02 \\
\hline $2008-09$ & 620.69 & 772.89 & 423.17 & 374.16 & 2190.91 \\
\hline $2009-10$ & 639.75 & 820.95 & 464.85 & 389.14 & 2314.95 \\
\hline
\end{tabular}

Table-4 : Region wise NO emissions per unit of electricity generation $(\mathrm{g} / \mathrm{kWh})$ during 2001-02 to 2009-10 ${ }^{[4]}$

\begin{tabular}{|l|l|l|l|l|l|}
\hline Year & \multicolumn{4}{|l}{ Region } & \multicolumn{4}{l|}{} & \\
\hline & Northern & Western & Southern & Eastern & India \\
\hline $2001-02$ & 4.62 & 4.32 & 4.19 & 3.8 & 4.29 \\
\hline $2002-03$ & 4.68 & 4.25 & 4.15 & 3.83 & 4.28 \\
\hline $2003-04$ & 5.0 & 4.36 & 3.85 & 3.97 & 4.34 \\
\hline $2004-05$ & 4.74 & 4.43 & 3.85 & 3.88 & 4.27 \\
\hline $2005-06$ & 4.73 & 4.43 & 3.8 & 3.6 & 4.22 \\
\hline $2006-07$ & 4.92 & 4.78 & 3.88 & 3.68 & 4.39 \\
\hline $2007-08$ & 4.78 & 4.69 & 4.07 & 3.69 & 4.38 \\
\hline $2008-09$ & 4.69 & 4.56 & 3.94 & 3.75 & 4.34 \\
\hline $2009-10$ & 4.67 & 4.64 & 4.07 & 3.72 & 4.34 \\
\hline
\end{tabular}

These estimates show that annual NO emissions in India have increased from 1.5 million tons in 200102 to 2.3 million tons in $2009-10$ at an average annual rate of 5.65 per cent. The Eastern region has the lowest NO emissions and the electricity generation while the Western region has the highest NO emissions and the electricity generation. ${ }^{[4]}$

Furthermore, it has also been analysed that $\mathrm{NO}_{\mathrm{x}}$ emissions from Indian thermal power plants over 1996 to 2010, has increased at least $70 \%$ over this period. ${ }^{[5]}$

For the whole of India, the average NO emissions were in the range of $4.2-4.4 \mathrm{~g} / \mathrm{kWh}$ over the nine year period of 2001-02 to 2009-10. ${ }^{\text {[4] }}$

\section{Typical Coal Fired Power Plant}

Fig 1 below depicts the flow diagram for a typical coal fired power plant. Combustion of coal takes place in the furnace where the heat energy generated from combustion is transferred to the water to form superheated steam to drive the turbine which further acts as a prime mover for the generator to generate electricity. 


\section{International Journal of Engineering Applied Sciences and Technology, 2021 \\ Vol. 6, Issue 3, ISSN No. 2455-2143, Pages 225-230 \\ Published Online July 2021 in IJEAST (http://www.ijeast.com)}

The products of combustion (also known as flue gas) are expelled from the furnace through the so called flue gas path. The flue gas path consists of the economiser (transfers heat to feed water), air preheater (transfer to heat to input air), Electrostatic Precipitator (removal of particulate matter), ID Fan (extracting flue gas) and the Chimney (exhaust for flue gases).

\section{NO $_{x}$ formation mechanism in Thermal Power Plants}

$\mathrm{NO}_{\mathrm{x}}$ is the term used for oxides of Nitrogen. This general term is used in Power Plant for the cumulative emissions of nitric oxide (NO), nitrogen dioxide $\left(\mathrm{NO}_{2}\right)$ and small quantities of other nitrogen-bearing species formed during combustion.

NOx emissions from combustion processes are about 90 to $95 \% \mathrm{NO}, \sim 5 \% \mathrm{NO}_{2}$, and $<1 \%$ of $\mathrm{N}_{2} \mathrm{O}$. This proportion largely depends on the combustion intensity. [7] and there are three principal mechanisms of $\mathrm{NO}_{\mathrm{x}}$ formation in combustion

Fig.2 : NOx formation from Nitrogen contained in Coal during Combustion ${ }^{[10]}$

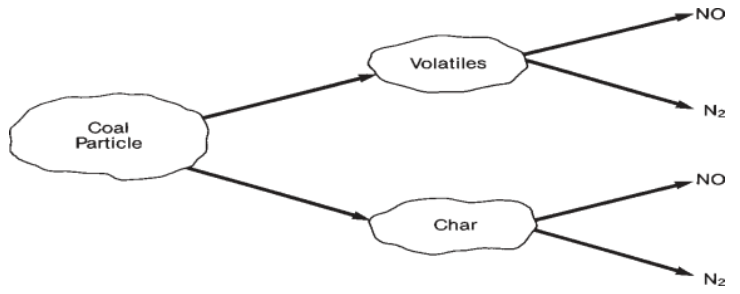
process: ${ }^{[7]}$
i. Thermal $\mathrm{NO}_{\mathrm{x}}$
ii. Fuel $\mathrm{NO}_{\mathrm{x}}$
iii. Prompt $\mathrm{NO}_{\mathrm{x}}$

\section{i. Thermal NO}

This contributes approx. $20 \%$ of the total $\mathrm{NO}_{\mathrm{x}}$ emission from the furnace. Thermal $\mathrm{NO}_{\mathrm{x}}$ is the $\mathrm{NO}_{\mathrm{x}}$ formed by the oxidation at high temperature of nitrogen found in the combustion air. The rate of formation depends on temperature as well as residence time. Under oxidizing conditions, above $2200^{\circ} \mathrm{F}$ $\left(1204^{\circ} \mathrm{C}\right)$, significant levels of $\mathrm{NO}_{\mathrm{x}}$ are usually formed with exponential increases as the temperature is increased.

Since the principal conditions for proper combustion, i.e. high temperature, long residence time and high turbulence, are also responsible for the increased rate of thermal $\mathrm{NO}_{\mathrm{x}}$ formation, a balance between effective combustion and controlled $\mathrm{NO}_{\mathrm{x}}$ formation is needed. ${ }^{[5]}$

\section{ii. Fuel NOx}

During combustion, the fuel bound nitrogen in nitrogen bearing fuels such as coal and oil is the major source of $\mathrm{NO}_{\mathrm{x}}$ emissions. During combustion of coal in furnace, $80 \%$ of the total uncontrolled NOx emissions is due to the fuel $\mathrm{NO}_{\mathrm{x}}$. Nitrogen present in coal is a part of the organic compounds of coal. This nitrogen is released as a free radical to ultimately form $\mathrm{NO}$ or $\mathrm{N}_{2}$, during combustion. The majority of $\mathrm{NO}_{\mathrm{x}}$ formation from fuel-bound nitrogen occurs through a series of reactions that are not fully understood. However, it is apprehended that this conversion takes place by two separate paths.

In the first path, during the initial phase of combustion, the oxidation of volatile nitrogen compounds takes place. During the release and prior to the oxidation of the volatile compounds, nitrogen reacts to form several intermediate compounds in the fuel-rich flame

Fig 1 : Typical Coal Fired Power Plant

\section{DIAGRAM OF A TYPICAL COAL-FIRED THERMAL POWER STATION}

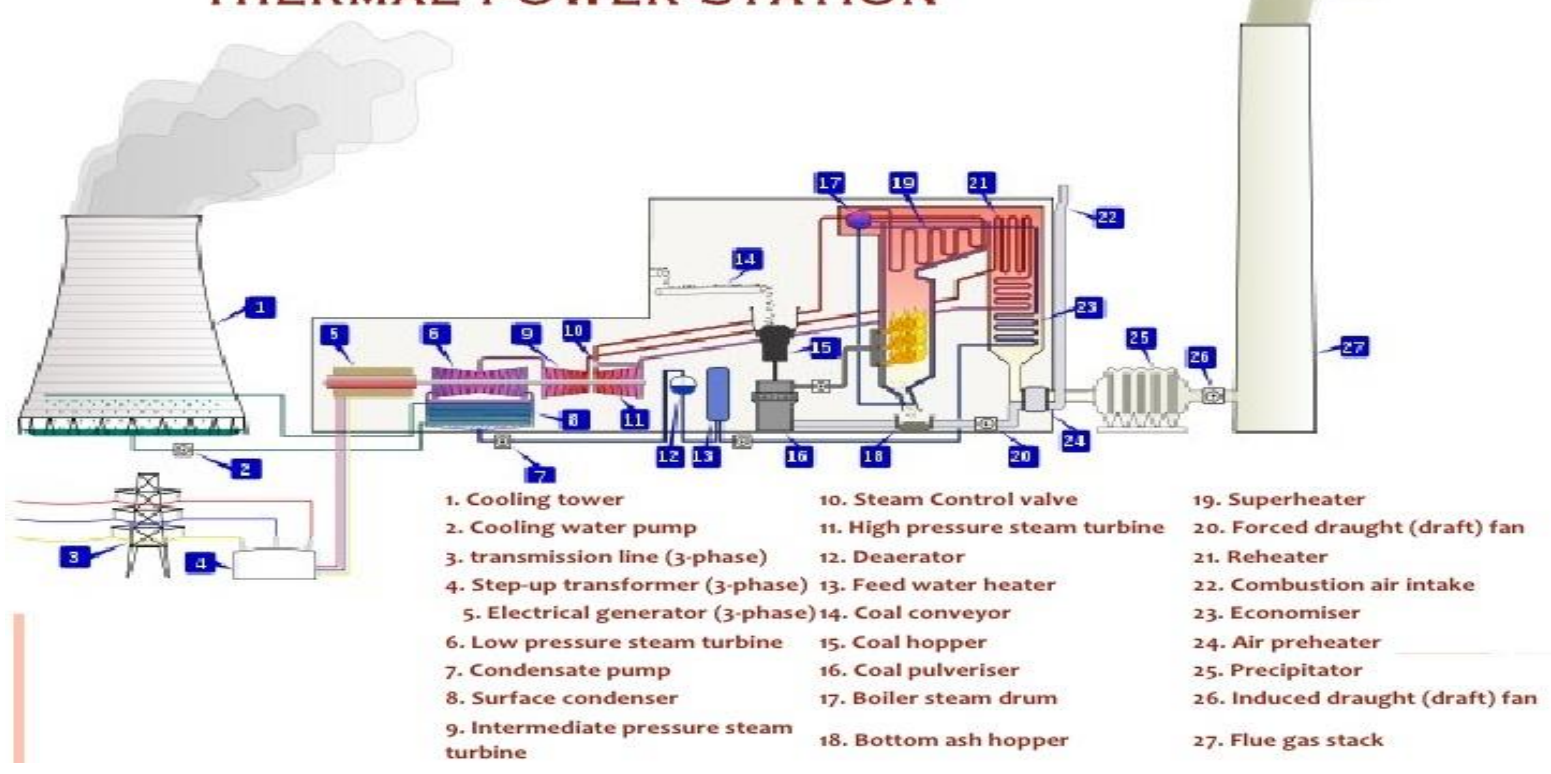




\section{International Journal of Engineering Applied Sciences and Technology, 2021 \\ Vol. 6, Issue 3, ISSN No. 2455-2143, Pages 225-230 \\ Published Online July 2021 in IJEAST (http://www.ijeast.com)}

regions.

Conversion of fuel-bound nitrogen to NOx is strongly dependent on the fuel/air stoichiometry but is relatively independent of variations in combustion zone temperature. Therefore, by controlling the oxygen available during the preliminary stages of combustion, this conversion can be controlled. A substantial reduction in $\mathrm{NO}_{\mathrm{x}}$ emissions by controlling stoichiometry in the initial devolatilization zone can be achieved by methods such as controlled fuel-air mixing and staged combustion. ${ }^{[5]}$

\section{iii. Prompt $\mathrm{NO}_{\mathrm{x}}$}

This is produced in fuel- rich conditions by a complex series of reactions between hydrocarbon radicals and molecular nitrogen in the flame zone, resulting in the formation of amines and cyano compounds and their subsequent oxidation to NO. It is a relatively small contributor to total $\mathrm{NO}_{\mathrm{x}}$ formation, especially in the combustion of coal and other nitrogen-containing fuels. ${ }^{[5]}$

\section{Control of NOx emission}

The control mechanisms envisaged for emission of NOx from Power Plants can be broadly categorised in two categories.

i. Control of NOx formation

(Reducing NOx formation during combustion)

ii. Post Combustion Control

(Capturing NOx formed after combustion.)
After combustion of fuel in the furnace, flue gas is formed which contains the pollutants including NOx. This flue gas, before being expelled to the atmosphere passes through a series of ducts and technological equipments (viz. Economizer, Air Preheater, Electrostatic Precipitator, Induced Draught Fans, FGD units) which have their distinct technological functions. Additional NOx control techniques are applied downstream of the combustion zone, i.e. after the furnace to achieve the further reductions.

There are two types of post-combustion methods, i.e. SCR (selective catalytic reduction) and SNCR (selective non-catalytic reduction). In both the methods, a reagent (or reagents) injected into the flue gas which reduces NOx to nitrogen (N2) and water $(\mathrm{H} 2 \mathrm{O})$ through a series of reactions. ${ }^{\text {[7] }}$

\section{Selective catalytic reduction (SCR)}

In this technology a reductant (generally ammonia or urea) is introduced into the hot flue gas through an injection grid. The flue gas with the ammonia passes through a catalyst (titanium dioxide with small amounts of vanadium, molybdenum, tungsten, or a combination of other active reagents) for a required residence time to achieve design performance (arranged generally in blocks or corrugated honeycomb structure) and the NOx reduction reactions occur within the
Fig 3 : NOx removal mechanism in SCR [10]

Economiser Side

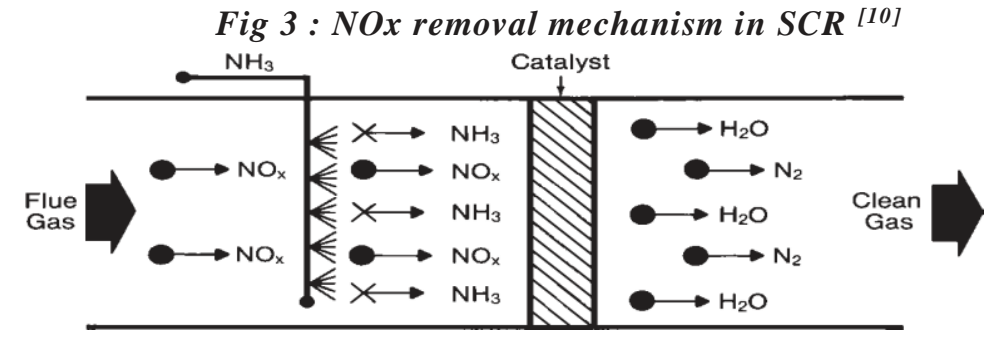

Air Pre Heater Side

\section{i. Control of $\mathrm{NO}_{\mathrm{x}}$ formation}

The formation of $\mathrm{NO}_{\mathrm{x}}$ can be normally controlled by the following methods. ${ }^{[7]}$

a) By reducing peak and average flame temperatures. - Controlled mixing burners to slow the combustion process.

b) Staged combustion - A portion of the combustion air is added initially to burn the fuel; the balance air is introduced in a phased manner to complete the combustion process.

c) Flue gas recirculation (FGR) - Mixing some of the flue gas with the combustion air at the burner which increases the amount of gas to be heated by the chemical energy in the fuel, resulting in reduction of flame temperature.

\section{ii. Post-combustion reduction}

micropores of the catalyst. ${ }^{[7]}$

$$
\begin{aligned}
& 4 \mathrm{NO}+4 \mathrm{NH}_{3}+\mathrm{O}_{2} \longrightarrow 4 \mathrm{~N}_{2}+6 \mathrm{H}_{2} \mathrm{O} \\
& \mathrm{NO}+\mathrm{NO}_{2}+2 \mathrm{NH}_{3} \longrightarrow 2 \mathrm{~N}_{2}+3 \mathrm{H}_{2} \mathrm{O}
\end{aligned}
$$

$\mathrm{SCR}$ can effectively reduce NOx levels leaving the boiler by $90 \%$ or greater depending on the specific project and space availability.

The ideal gas temperature for NOx reduction ranges from 700 to $750^{\circ} \mathrm{F}$ ( 371 to $399^{\circ} \mathrm{C}$ ).

For installing SCR, there are two possible locations / variations

Hot side/high dust

The typical SCR system is located at the economizer outlet, preceding the air heater. This is the hot side location for all fuel types and the high dust location for ash-laden fuels. 


\section{International Journal of Engineering Applied Sciences and Technology, 2021 \\ Vol. 6, Issue 3, ISSN No. 2455-2143, Pages 225-230 \\ Published Online July 2021 in IJEAST (http://www.ijeast.com)}

\section{Cold side/low dust}

An alternative SCR location is after the air heater and particulate collection or flue gas desulfurization (FGD) systems. These systems must also include a method to increase the flue gas temperature.

Since, the temperature at this location is below the ideal gas temperature for NOx reduction range, hence additional arrangement is required for increasing the flue gas temperature. This may include gas-to-gas air heaters, high pressure steam heat exchangers, duct burners, or a combination of these components. When installed after an FGD system or on a low sulfur fuel and after the Electro Static Precipitator, this typically results in a design gas temperature of 600 to $650^{\circ} \mathrm{F}$ (316 to $343^{\circ} \mathrm{C}$ ).

Selective non catalytic reduction (SNCR) SNCR technologies inject a reducing agent (generally ammonia or urea) into $\mathrm{NO}_{\mathrm{x}}$ laden flue gas within a specific temperature zone. The reducing agent has to be properly mixed with the flue gas for effectiveness of the process. Finally, the mixture must have adequate residence time at temperature for the reduction reactions to occur.

Ammonia

$$
\begin{gathered}
4 \mathrm{NO}+4 \mathrm{NH}_{3}+\mathrm{O}_{2} \rightarrow 4 \mathrm{~N}_{2}+6 \mathrm{H}_{2} \mathrm{O} \\
\text { Urea } \\
4 \mathrm{NO}+2 \mathrm{CO}\left(\mathrm{NH}_{2}\right)_{2}+\mathrm{O}_{2} \longrightarrow 4 \mathrm{~N}_{2}+6 \mathrm{H}_{2} \mathrm{O}+2 \mathrm{CO}_{2}
\end{gathered}
$$

The acceptable temperature range for either reaction is 1400 to $2000^{\circ} \mathrm{F}$ (760 to $1093^{\circ} \mathrm{C}$ ), although temperatures above $1700^{\circ} \mathrm{F}\left(927^{\circ} \mathrm{C}\right)$ are preferred. ${ }^{[8]}$

\section{PROBLEM FORMULATION}

The predominant method of thermal NOx control is by using low $\mathrm{NO}_{\mathrm{x}}$ burners and using a catalyst for reduction. But, these low $\mathrm{NO}_{\mathrm{x}}$ burners are effective only for reducing thermal $\mathrm{NO}_{\mathrm{x}}$ which contribute to about $20 \%$ of $\mathrm{NO}_{\mathrm{x}}$ formation. Hence, the alternative left for major NOx control is in post combustion by utilising catalytic reduction (either SCR or SNCR).

\section{Issues and Limitations}

For control of Post Combustion $\mathrm{NO}_{\mathrm{x}}$ in Coal Fired Power Plants, both the SCR \& SNCR technologies have their own restrictions and their provenness for the high ash Indian Coal is yet to be established.

Indian coals here have high ash content $(40-45$ $\%) .{ }^{[15]}$ Unfortunately, nowhere in the world are such high ash fuel burnt in Power plants and SCR has not been installed in units using fuel with an ash content exceeding $60 \mathrm{~g} / \mathrm{m}^{3}$, well below Indian average of about $80 \mathrm{~g} / \mathrm{m}^{3} .{ }^{[9]}$
These technologies for complying are mostly offthe-shelf and still there is certain uncertainty about the exact level of modification required in these technologies for NOx reduction considering the high ash Indian coal. ${ }^{[7]}$

\section{i. Issues and Limitations in SCR System}

SCR systems are prone to choking and contamination during operation as the catalysts available in the market is generally porous in construction. And, these pores are vulnerable to choking by the components present in combustion/fuel gas. The ideal gas temperature for $\mathrm{NO}_{\mathrm{x}}$ reduction ranges from 700 to $750^{\circ} \mathrm{F}$ (371 to $\left.399^{\circ} \mathrm{C}\right)$. Hence, the typical SCR system is located at the economizer outlet, preceding the air heater which is also the high dust location for ash-laden fuels. ${ }^{[7]}$ This causes adverse ash effects on the catalyst. And this effect will intensify especially with the high ash Indian Coal.

Also, the region of the boiler system between the economizer and airheater experiences temperature fluctuations with varying loads and fuel composition. ${ }^{[7]}$ As a result, SCR system design must accommodate swings in flue gas temperature while maintaining the desired performance, without affecting boiler operation. An alternative SCR location is after the air heater and particulate collection or flue gas desulfurization (FGD) systems. But the temperature at this region is below the ideal gas temperature for $\mathrm{NO}_{\mathrm{x}}$ reduction range. Hence, an aditional method to increase the flue gas temperature is necessitated in this case.

Another issue with the SCR technology is the incomplete reaction of ammonia and NOx (ammonia slip) which may result in one or more problems, including: ${ }^{[7]}$

- Formation of ammonium sulphate and ammonium bisulphate due to the sulphur content of the fuel or other ammonium salts which can plug or corrode the air heater and other downstream components;

- Ammonia absorption on fly ash, which may make disposal or reuse of the ash difficult.

\section{ii. Issues and Limitations in SNCR System}

The reaction involved requires a sufficient reaction time within a certain narrow temperature range, to be effective. If the temperature is low, the reaction between ammonia and NO does not take place. This unreacted ammonia remains in the flue gas and may react with other combustion species, such as sulfur trioxide $\left(\mathrm{SO}_{3}\right)$ to form unwanted ammonium salts. Also, at higher temperatures above $1093{ }^{\circ} \mathrm{C}$, ammonia decomposes: ${ }^{[7]}$

$$
4 \mathrm{NH}_{3}+5 \mathrm{O}_{2} \rightarrow 4 \mathrm{NO}+6 \mathrm{H}_{2} \mathrm{O}
$$




\section{International Journal of Engineering Applied Sciences and Technology, 2021 \\ Vol. 6, Issue 3, ISSN No. 2455-2143, Pages 225-230 \\ Published Online July 2021 in IJEAST (http://www.ijeast.com)}

In such conditions, NO is further created instead of being removed.

A further complication is mixing. As the walls are cooler than the centre, it may result in more $\mathrm{NO}$ formation at the centre which reduces as we move farther towards the walls,. Thus, more ammonia must find its way to the centre and less near the walls, otherwise NO in the centre meets insufficient ammonia for reduction and excess ammonia near the walls slips through. ${ }^{[7]}$

Theoretically, the same efficiency of about $90 \%$ is achieved in both the selective non-catalytic reduction and selective catalytic reduction (SCR), the actual practical results are unpredictable due to the practical constraints of temperature, time, and mixing.

The high ash content may cause choking of the catalyst blocks in SCR System while due to a very narrow operating range of temperature, the SNCR system is not as efficient as SCR System and is only suitable where moderate reductions are required. ${ }^{[9]}$

Concern about the high ash coals has often been discussed and presented at various technological forums but no concrete solution has yet been evolved.

Apart from the technological issues, one of the judging factor which cannot be overlooked is that these technologies require higher capital and operating cost, as addition/ modification of any additional technology will require monetary investments which in turn will further increase the cost of generation.

Hence, considering the complications involved, the MOEF in its latest notification has further extended its deadline and the power plants are required to meet the environmental emission norms by 2023 to 2024.

\section{CONCLUSION}

Though research and development to explore for effective measures of NOx control while maintaining equilibrium between cost and effectiveness is mandated, the emphasis should also be on time bound results and subsequent implementation. As every delay caused in the implementation of these pollution control measures are leading to emission of more harmful particles in the environment.

\section{REFERENCES}

1. Central Electricity Authority (Ministry of Power, Govt. of India) Report : "All India Installed Capacity (in MW) of Power Stations (as on 31.03.2020)",

2. Amendment of "Environment (Protection)
Rules, 1986" by Ministry Of Environment, Forest and Climate Change, 07.12.2015.

3. Central Electricity Authority (Ministry of Power, Govt. of India) Report : "Monthly Report on Broad Status of Thermal Power Projects in the Country - Dec 2017'.

4. Rahul Tongia \& Deborah Seligsohn : "Challenges and Recommendations for Meeting the Upcoming 2017 Standards for Air Pollution from Thermal Power Plants in India" Feb 2017.

5. Moti L. Mittal, and Chhemendra Sharma \& Richa Singh, "Estimates of Emission from Coal Fired Thermal Power Plants in India" International Emission Inventory Conference, Tampa, Florida, August 2012.

6. Zifeng Lu and David G. Streets "Increase in NOx emissions from Indian thermal power plants during 1996-2010: Unit-based inventories and multi-satellite observations" Environment Science and Technology Journal, 25 June 2012.

7. The Babcock \& The Wilcox Company "Steam, Its Generation \& Use". 41st Edition, 2005.

8. John L. Sorrels, David D. Randall, Carrie Richardson Fry, and Karen S. Schaffner RTI International Research Triangle Park, NC 27709 : "Selective Noncatalytic Reduction" , May 2016.

9. ISGEC Presentation : "DeNOx System Issues \& Challenges", CSE Roundtable on Pollution Control Technology for coal based power plants at Silver Oak hall -II, India Habitat Centre, New Delhi, 6th July 2016. 